\title{
Powszechna deklaracja niezależności uniwersytetów
}

\section{ZESPÓŁ XVII}

\section{KEYWORDS}

independence of universities; freedom of scientific research; mission of university

ACKNOWLEDGEMENT / ŹRÓDłO PRZEKŁADU

Groupe XVII. (2009). Déclaration d'indépendance des universités. Cabiers critiques de philosophie, 8, 221-224. 
Celem poniższego projektu deklaracji byto spisanie zasad, na których opiera sie istnienie uniwersytetów. Sa one na tyle kluczowe, że jeżeli nie sa przestrzegane, postugiwanie się terminem "uniwersytet” stanowi nadużycie.

Zespót, który je zredagowat, powstat na uniwersytecie Paris VIII, przy okazji strajku oprotestowującego rozporządzenie minister Valérie Pécresse dotyczace statusu nauczycieli akademickich oraz ustawe o autonomii i odpowiedzialności uniwersytetów. Projekt rozrastat sie $w$ miare kolejnych spotkań roboczych. Nie uważamy pracy nad nim za zakończona a jego treści za ostateczna. Został już przettumaczony na kreolski, niderlandzki, grecki, portugalski, biszpański, angielski $i$ arabski, a trwaja prace nad ttumaczeniami na inne jezyki. Pragniemy przede wszystkim, żeby zostat jak najszerzej rozpowszechniony $i$ dotart do wszystkich zainteresowanych osób, aby mogły one wyrazić swoje zdanie krytyczne lub sugestie i stały sie wspótautorami.

Wstępne rozpowszechnienie na niewielka skale we Francji oraz za granica pozwolito ulepszyć i uzupetnić wersje wyjściowa. Upowszechnianie pozwoli na dalsze udoskonalenie i rozbudowanie tekstu. Wszyscy ci, którzy wzięli lub wezma udziat $w$ opracowywaniu go, stali się bądź stana ipso facto jego propagatorami; może ich być nieskończenie wielu.

Komitet (Saint-Denis, 1 marca 2009 roku)

\section{PREAMBUŁA}

Ludzkiego umysłu nie pętają żadne ograniczenia poza tymi, które on sam sobie narzuca, bo wszystkie je stwarza, myśląc. Najdonioślejsze są myśli będące wynikiem najwyższych wymagań. Wymagania te opisywano przy użyciu takich pojęć jak: prawda, twórczość, piękno, sprawiedliwość, rozum, szat. Sztuka, nauka, technika, rzemiosło: wszystkie te dyscypliny gwarantują ich istnienie i wyrażają je. Odrzucenie tych wymagań grozi upadkiem każdej władzy, czy to politycznej, religijnej, ekonomicznej czy jakiejkolwiek innej.

Biorąc pod uwagę, że te wymagania oraz warunki umożliwiające ich poszanowanie powinny zostać zapewnione niezależnie od władzy, która się do nich odwołuje lub utrzymuje, iż im służy; zważywszy, że uniwersytety odpowiadają w tym zakresie przed narodami w ich formie przeszłej, teraźniejszej i przyszłej, my, którzy na różne sposoby uczestniczyliśmy w wykonywaniu powszechnego prawa i obowiązku myślenia, postanowiliśmy sformułować podstawowe zasady, których przestrzeganie jest koniecznym warunkiem poszanowania wspomnianych wymagań.

\section{ARTYKUE I}

Niezależne myślenie polega na możliwości rozwijania zdolności poznawczych wytwarzających dzieła i wiedzę bez ingerencji czynników zewnętrznych. 
Jedynym ograniczeniem niezależności myślenia jest konieczność zapewnienia innym możliwości sprawdzenia, poświadczenia i oceny jego poprawności. Może tego dokonywać jedynie wspólnota równych sobie ludzi, uznających niezależność uniwersytetów.

\section{ARTYKUŁ II}

Każdy mężczyzna i każda kobieta posiada, bez względu na okoliczności, niezbywalne prawo do weryfikacji swojej równości intelektualnej w konfrontacji z innymi.

\section{ARTYKUŁ III}

Wszystkie osoby uczestniczące w badaniach, nauczaniu czy studiach mają prawo do niezależnego myślenia. Prawo to nie jest uzależnione od stanowiska zajmowanego na uniwersytecie, narodowości, pochodzenia społecznego, wyznania, przynależności etnicznej, wieku ani tożsamości płciowej czy seksualnej.

\section{ARTYKUŁ IV}

Działalność uniwersytetów opiera się na różnorodności językowej i kulturowej. Ich misją jest przyczynianie się do niczym nieograniczonej kreatywności.

\section{ARTYKUŁ V}

Uniwersytety popierają i promują swobodny przepływ osób i myśli.

\section{ARTYKUŁ VI}

Swobodny przepływ myśli i wiedzy opiera się na bezwarunkowym prawie dostępu do wszelkich środków i źródeł poznania. Korzystania z niego nie może ograniczać żadna forma cenzury.

\section{ARTYKUŁ VII}

Każda osoba uczestnicząca $\mathrm{w}$ badaniach, nauczaniu lub studiach musi mieć możliwość krytycznego myślenia, nie będąc narażoną na cenzurę, represje czy prześladowania. 


\section{ARTYKU€ VIII}

Uniwersytety muszą być wyłączone spod kontroli sił porządkowych oraz zbrojnych. Ich siedziba znajduje się tam, gdzie na zasadzie dobrowolności zbierają się ich przedstawiciele.

\section{ARTYKUŁ IX}

Wartość myśli podlegającej ograniczeniu prawdziwości opiera się wyłącznie na wymogu jej sprawdzalności. Jej ocena na uniwersytecie należy do tych, którzy w badaniach, nauczaniu i studiach wcielają w życie ten wymóg. Ma ona charakter jawny i podlega polemice.

\section{ARTYKUŁ X}

Misja uniwersytetu ma charakter publiczny. Jako taka musi być zagwarantowana.

\section{ARTYKUモ XI}

Celem polityki naukowej jest wyłącznie wytwarzanie dzieł i narzędzi poznania. Działalność naukowa nie ma na celu rentowności, więc ta ostatnia nie może decydować o jej przebiegu ani wysokości finansowania. Autonomię działalności powinny zapewniać władze państwowe.

\section{ARTYKU乇 XI}

Żadna osoba chcąca kontynuować naukę nie powinna być zmuszana do rezygnowania z niej z powodów finansowych bądź związanych z praktyczną organizacją uniwersytetu. Tym bardziej nie może być zmuszana do obciążania swojej przyszłości czy zadłużania się w celu finansowania swojej nauki ani do zgadzania się na poniżanie swojej godności. Powinna otrzymywać wszelkie konieczne wsparcie finansowe.

\section{ARTYKUŁ XIII}

Każda osoba pracująca na uniwersytecie jest pełnoprawnym członkiem wspólnoty, która przyznaje wszystkim równe prawa, w tym prawo do szacunku. 


\section{ARTYKUŁ XIV}

Jedynie te spośród ośrodków naukowych, badawczych i twórczych, które stawiają sobie za cel wcielanie w życie niniejszych zasad, mogą być określane jako uniwersytety.

\section{ARTYKUŁ XV}

Społeczeństwa i państwa gwałcące niniejsze zasady nie posiadają uniwersytetów.

\section{ARTYKUŁ XVI}

Każdy uniwersytet pragnący stosować niniejsze zasady ma prawo uzyskać ochronę ze strony innych uniwersytetów oraz organizacji międzynarodowych. Każdy uniwersytet będący sygnatariuszem niniejszej deklaracji zobowiązuje się przyjść z pomocą temu, który o taką pomoc występuje w oparciu o opisane tu zasady.

Komitet redakcyjny artykułów Powszechnej deklaracji niezależności uniwersytetów Uniwersytet Paris VIII

Z jezzyka francuskiego przełożyt Przemystaw SZCZUR*

* Dr, asystent, Wydział Filologii, Uniwersytet Pedagogiczny w Krakowie. E-mail: przemyslaw. szczur@up.krakow.pl. 
